\title{
Regulation of Interleukin 3 Gene Induction in Normal Human T Cells
}

\author{
Susan C. Guba, ${ }^{\star}$ Gregory Stella, ${ }^{\star}$ Laurence A. Turka, ${ }^{\star}$ Carl H. June, ${ }^{\ddagger}$ Craig B. Thompson, ${ }^{\star \$} \|$ and Stephen G. Emerson ${ }^{\star}$ \\ ${ }^{\S}$ Howard Hughes Medical Institute and Departments of ${ }^{*}$ Medicine and "Microbiology/Immunology, University of Michigan, \\ Ann Arbor, Michigan 48109; and ${ }^{\ddagger}$ Naval Medical Research Institute, Bethesda, Maryland 20814
}

\begin{abstract}
The regulation of $\mathrm{IL-3}$ gene induction in human peripheral blood $T$ cells was studied. IL-3 gene expression was inducible by crosslinking of the $T$ cell receptor/CD3 complex using anti-CD3 MAb G19-4. Anti-CD3-induced IL-3 gene expression was found to be limited to the $\mathrm{CD}^{2} 8^{+} \mathrm{T}$ cell subset and could be augmented by costimulating $T$ lymphocytes with antibodies directed against CD28. IL-3 expression could also be induced by costimulation of $T$ cells with both phorbol ester and ionomycin, which are thought to mimic the intracellular effects of $T$ cell receptor-antigen interaction. However, unlike other lymphokines such as IL-2 or granulocyte-macrophage colonystimulating factor, IL-3 gene expression is not induced by stimulation of cells with phorbol myristate acetate and anti-CD28. We conclude that IL-3 gene regulation is under stringent control since IL-3 gene expression occurs only in the $\mathrm{CD}^{+} 8^{+}$subset of $T$ cells, and since IL-3 induction obligately requires increased intracellular calcium.
\end{abstract}

\section{Introduction}

Hematopoiesis appears to be regulated by the effects of a complex series of growth factors. One such hematopoietic growth factor is the lymphokine IL-3. IL-3 is of particular interest because it exerts a broad range of hematopoietic activities on both multilineage and committed progenitor cells (1-4). In serum-free cultures IL-3 supports the early division of progenitor cells of erythroid, myeloid, and megakaryocytic lineage, as well as multilineage progenitor cells (5). The cellular source of IL-3 appears to be quite restricted. Unlike granulocyte colonystimulating stimulating factor which is produced by monocytes and fibroblasts (2), or granulocyte-macrophage colonystimulating factor (GM-CSF) ${ }^{1}$ which is produced by fibroblasts, endothelial cells, epithelial cells, and T lymphocytes ( 2 , $6,7)$, IL-3 is produced uniquely by T lymphocytes $(2,8)$. Furthermore, unlike other T cell lymphokines IL-3 gene expression is only weakly inducible with lectin stimulation of $\mathrm{T}$ cells $(8,9)$. These observations suggest that the expression of IL-3 is either restricted to a subset of $\mathrm{T}$ cells or that the conditions for maximal IL-3 gene expression are more stringent than for other $\mathrm{T}$ cell-derived lymphokines. Thus, because IL-3 is a broadly active molecule, and because the conditions of IL-3

Address reprint requests to Dr. Susan C. Guba, MSRB I, Room 5504, 1150 West Medical Center Drive, Ann Arbor, MI 48109.

Received for publication 26 May 1989 and in revised form.

1. Abbreviations used in this paper: GM-CSF, granulocyte-macrophage colony-stimulating factor; PDBU, phorbol dibutyrate.

J. Clin. Invest.

(c) The American Society for Clinical Investigation, Inc.

0021-9738/89/12/1701/06 \$2.00

Volume 84, December 1989, 1701-1706 gene induction are poorly understood, we sought to examine the physiological basis for the restricted expression of the IL-3 gene.

The best characterized pathway of $T$ cell activation occurs through the T cell receptor (TCR)/CD3 complex. Stimulation of this pathway induces a variety of $\mathrm{T}$ cell lymphokine/cytokine genes (10). Activation of the TCR/CD3 pathway is thought to result from the interaction of the receptor with specific soluble antigen presented on an MHC molecule by macrophages, B cells, or other antigen-presenting cells, and by foreign cell surface antigens, e.g., viral proteins. Binding of antigen to the TCR/CD3 complex activates phospholipase $\mathrm{C}$. Phospholipase $\mathrm{C}$ hydrolyzes phosphatidylinositol to inositol triphosphate and diacylglycerol. Inositol triphosphate increases the intracellular calcium concentration both by mobilizing intracellular calcium stores (e.g., from the endoplasmic reticulum) and by increasing extracellular calcium flux. Diacylglycerol induces translocation of protein kinase $\mathrm{C}$ from the cytosol to the plasma membrane (11-15). Polyclonal, normal $T$ cells can be activated by antibodies that activate the TCR/ CD3 complex by binding to one of the invariant chains of the complex. Alternatively, $\mathrm{T}$ cell receptor activation can be mimicked by the combination of a phorbol ester such as phorbol myristate acetate (PMA) and the calcium ionophore ionomycin. PMA directly activates protein kinase $\mathrm{C}$, and the calcium ionophore ionomycin increases intracellular calcium levels (16). Recent work has shown that the expression of several lymphokine genes can be further augmented by costimulation of the TCR/CD3 complex and a 44-kD cell surface protein termed CD28 (10). Alternatively, the combination of PMA and anti-CD28 stimulation can activate $T$ cells in an apparently calcium-independent fashion $(10,17)$.

We have used the TCR/CD3 pathway to study the regulation of IL-3 gene induction. We have found that T cell IL-3 gene expression is induced by TCR/CD3 complex activation alone, occurs exclusively in the $\mathrm{CD} 28^{+}$subset of $\mathrm{T}$ cells, and is augmented by costimulation with anti-CD28. The effects of the TCR/CD3 activation on IL-3 gene expression can be mimicked by PMA and ionomycin. However, unlike other lymphokines (10) the alternative $T$ cell activation pathway induced by PMA and MAb 9.3 (anti-CD28) does not result in IL-3 gene expression. This suggests there is an obligate calcium requirement for IL-3 gene expression since soluble MAb 9.3 does not increase intracellular calcium levels (17). Thus, IL-3 gene expression is under stringent regulation, having, in the absence of cell surface signals, an obligate calcium requirement.

\section{Methods}

Cells. PBMC $\left(2 \times 10^{8}-2.5 \times 10^{9}\right)$ were isolated from buffy coats obtained by leukapheresis or phlebotomy of healthy donors $21-31$ yr old using density gradient centrifugation. In some experiments the CD28 ${ }^{+}$ and $\mathrm{CD} 28^{-}$subsets of $\mathrm{T}$ cells were isolated from the PBMC by negative 

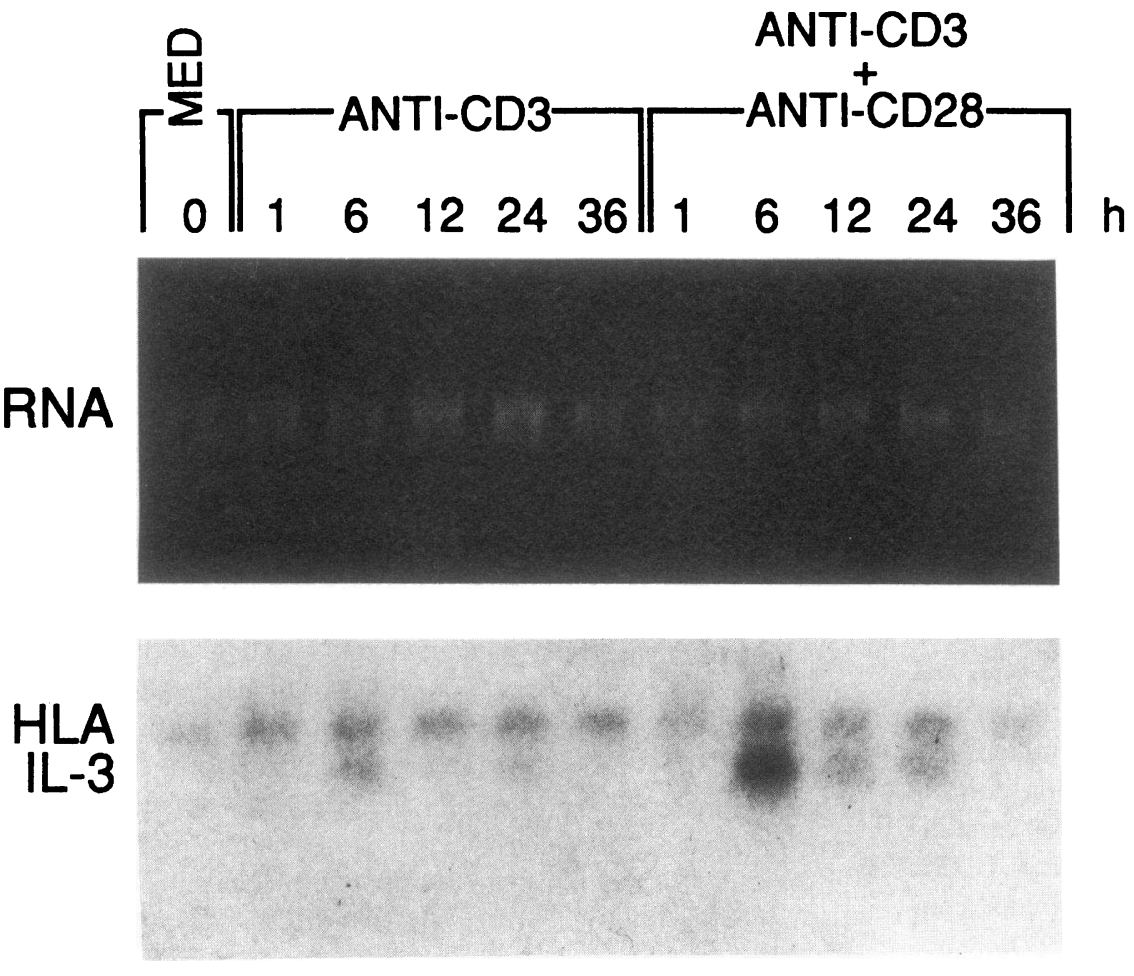

Figure 1. Induction of IL-3 gene expression by anti-CD3 or anti-CD3 with anti-CD28. Purified resting human peripheral blood $\mathrm{T}$ cells cultured with RPMI 1640/10\% FCS (MED) for $0 \mathrm{~h}$, MAb G19-4 (ANTI-CD3) immobilized on coated plastic dishes for $1,6,12,24$, or $36 \mathrm{~h}$, immobilized MAb G19-4 (ANTICD3) plus soluble MAb $9.3($ ANTI-CD28) at 1 $\mu \mathrm{g} / \mathrm{ml}$ for $1,6,12,24$, or $36 \mathrm{~h}$. RNA was extracted and equalized on nondenaturing $1 \%$ agarose gels (top). The Northern blots were transferred to nitrocellulose filters and hybridized sequentially with HLA Class I and IL-3 cDNAs. The HLA probe is visualized in the upper band of the lower panel; the IL-3 probe is visualized in the lower band of the lower panel. The IL-3-labeled autoradiograph was exposed to XAR film for $2 \mathrm{wk}$. Comparison of IL-3 gene expression was performed by scanning densitometry. selection using immunoabsorption (18). Taking advantage of the reciprocal expression of the cell surface antigens CD11 and CD28 on T cells, the $\mathrm{CD} 28$ and $\mathrm{CD} 28^{+}$subsets were separated. To isolate $\mathrm{CD} 28^{+}$ $\mathrm{T}$ cells, the PBMC were incubated at $4^{\circ} \mathrm{C}$ with saturating quantities of MAbs 60.1 (CD11), 1F5 (CD20), FC-2 (CD16), and 20.3 (CD14) to remove $B$ cells, monocytes, large granular lymphocytes, and $\mathrm{CD} 28^{-} \mathrm{T}$ lymphocytes. Alternatively, $\mathrm{CD} 28^{-}$cells were prepared by incubating with the MAb 9.3 (CD28). The cells were washed to remove unbound antibodies and then incubated with goat anti-mouse Ig-coated magnetic particles (Advanced Magnetics Institute, Cambridge, MA). The antibody-coated cells bound to the magnetic beads were removed by magnetic separation. Cell purification was monitored by flow cytometry and histochemistry. Cells were stained with FITC-conjugated CD2 MAb OKT 11 (Coulter Electronics, Inc., Hialeah, FL) and were $>98 \%$ $\mathrm{CD} 28^{+}$, and $<1 \% \mathrm{CD} 28^{+}$, respectively, when compared with a nonbinding, isotype-matched FITC-labeled control antibody. Residual monocytes were quantitated by staining for nonspecific esterase and were $<0.1 \%$ in purified cell populations used in this study. Viability was $>99 \%$ as measured by trypan blue staining.

MAbs. The MAbs 9.3 (anti-CD28) and G19-4 (anti-CD3) were produced as previously described $(19,20)$.

Activation of $T$ cells. PBMC or CD28 $8^{+}$lymphocytes were cultured at $1 \times 10^{6} / \mathrm{ml}$ in RPMI $1640 / 10 \%$ FCS at $37^{\circ} \mathrm{C}$. To stimulate T cells by the TCR/CD3 pathway, cells were cultured on plastic petri dishes coated with MAb G19-4 (anti-CD3). In some experiments soluble MAb 9.3 (anti-CD28) was added at $1 \mu \mathrm{g} / \mathrm{ml}$. The cells were incubated between 1 and $36 \mathrm{~h}$ and then harvested.

In some experiments cells were activated by stimulation with PHA at $10 \mu \mathrm{g} / \mathrm{ml}$ (Wellcome Diagnostics, Research Triangle Park, NC). Resting PBMC were cultured in $25-\mathrm{cm}^{2}$ tissue culture flasks (Corning Glass Works, Corning, NY) at $1 \times 10^{6}$ cells/ml in RPMI $1640 / 10 \%$ FCS for $12 \mathrm{~h}$ at $37^{\circ} .10 \mu \mathrm{g} / \mathrm{ml}$ PHA was then added to the treated cultures and the cells were harvested at $1,6,12$, and $24 \mathrm{~h}$.

In other experiments PBMC, purified CD $28^{+} \mathrm{T}$ cells, or purified CD28- $\mathrm{T}$ cells were directly stimulated with PMA at $3 \mathrm{ng} / \mathrm{ml}$ (Sigma Chemical Co., St. Louis, MO) or phorbol dibutyrate (PDBU) at 100 $\mathrm{ng} / \mathrm{ml}$ (LC Services Corp., Woburn, MA) with or without ionomycin at 300-800 ng/ml (Calbiochem-Behring Corp., San Diego, CA). The sol- uble MAb 9.3 was added to some cultures at a concentration of 1.0 $\mu \mathrm{g} / \mathrm{ml}$. The incubations were stopped at the appropriate serial time points and the cells were harvested for RNA.

Determination of IL-3 mRNA half-life. Purified resting CD28 ${ }^{+} \mathrm{T}$ cells were cultured in RPMI $1640 / 10 \%$ FCS at $1 \times 10^{6} / \mathrm{ml}$. The CD $28^{+}$ $\mathrm{T}$ cells were stimulated for $3 \mathrm{~h}$ by culturing on MAb G19-4 (antiCD3)-coated plastic tissue culture plates, with or without the addition of MAb 9.3 (anti-CD28) at $1 \mu \mathrm{g} / \mathrm{ml}$. At $3 \mathrm{~h}$ RNA synthesis was inhibited by addition of $10 \mu \mathrm{g} / \mathrm{ml}$ actinomycin D (Sigma Chemical Co.), to the culture medium. The cells were harvested at 15,45 , and $90 \mathrm{~min}$ after the addition of actinomycin D for extraction of total cellular RNA.

Northern (RNA) blot analysis. The cells were harvested and total cellular RNA was isolated using the guanidinium isothiocyanate method (20). RNA content of individual samples was equalized by ethidium bromide staining after separation on $1 \%$ nondenaturing agarose gels (21). The equalized RNA samples were then separated on $1 \%$ agarose-formaldehyde gels and transferred to nitrocellulose. Nick translated ${ }^{32} \mathrm{P}$-labeled cDNA probes were hybridized to the filters in $50 \%$ formamide- $10 \%$ dextran sulfate- $5 \times$ standard saline citrate (SSC; $1 \times \mathrm{SSC}$ is $0.15 \mathrm{M} \mathrm{NaCl}$ and $0.015 \mathrm{M}$ sodium citrate), $1 \times$ Denhardt's

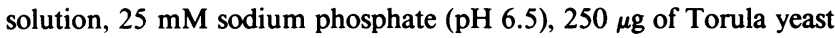
$\mathrm{RNA} / \mathrm{ml}$ with a probe concentration of $10^{6} \mathrm{cpm} / \mathrm{ml}$ at $42^{\circ} \mathrm{C}$ for $16-20$ h. After hybridization the filters were washed twice for $5 \mathrm{~min}$ at $22^{\circ} \mathrm{C}$ in $1 \times$ SSC $-0.1 \%$ SDS, then twice for $30 \mathrm{~min}$ at $55^{\circ} \mathrm{C}$ in $0.1 \times$ SSC $-0.1 \%$ SDS. Autoradiography was performed by exposing XAR film (Eastman Kodak Co., Rochester, NY) to the Northern blot filters at $-70^{\circ} \mathrm{C}$. Quantitation of band intensities on the Northern blot autoradiographs was performed by scanning densitometry as previously described (22).

$D N A$ probes. The cDNA probes used resulted from nick translation of gene-specific inserts (100 ng). The inserts were obtained after digestion with the appropriate endonucleases of the plasmid in which they were propogated. Digestion was followed by separation on low melting point agarose. The IL-3 probe is a $1.0-\mathrm{kb}$ Xho I cDNA fragment (9), the IL-2 probe is a $1.0-\mathrm{kb}$ Pst I cDNA fragment (23), the GM-CSF probe is a 700-bp Eco RI-Hind III fragment (24), and the HLA probe is a 1.4-kb Pst I fragment (25). These cDNA probes were added at a final concentration of $10^{6} \mathrm{cpm} / \mathrm{ml}$ of hybridization mix. 

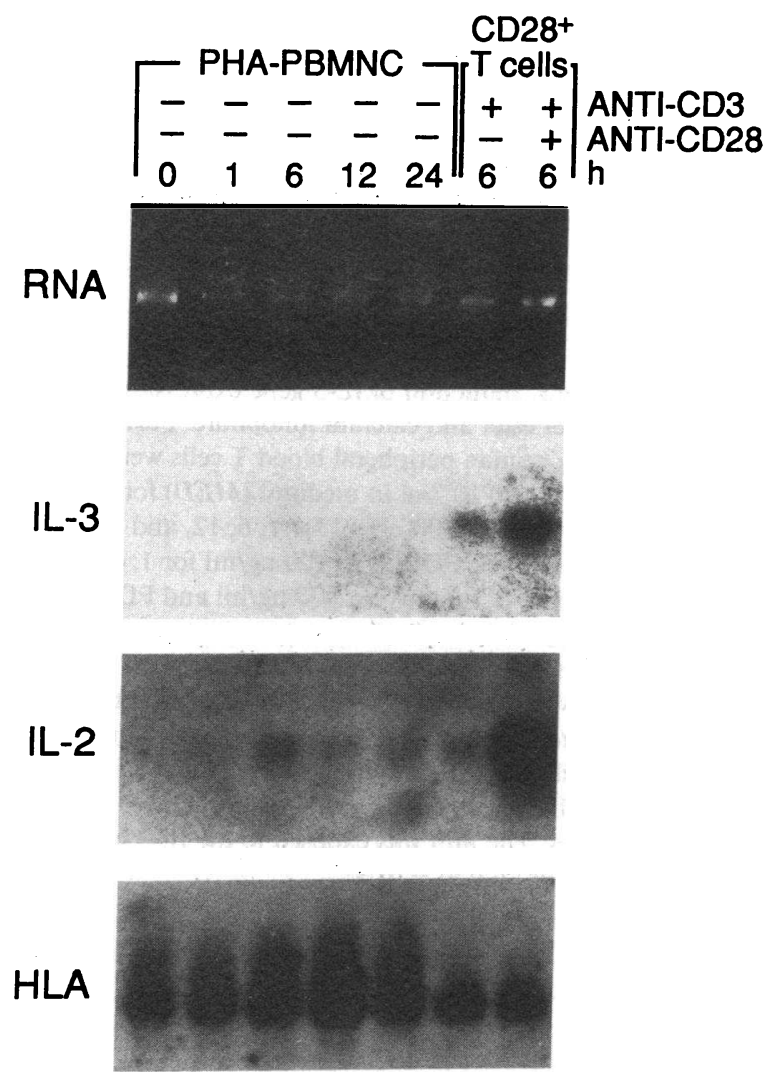

Figure 2. Induction of IL-3 gene expression by PHA. Resting human PBMC $(P B M N C)$ were cultured at $1 \times 10^{6} / \mathrm{ml}$ in RPMI $/ 10 \%$ FCS overnight, then stimulated with $10 \mu \mathrm{g} / \mathrm{ml}$ PHA for $0,1,6,12$, and 24 h. Alternatively, purified resting human peripheral blood $\mathrm{T}$ cells were cultured with immobilized MAb G19-4 (ANTI-CD3) for $6 \mathrm{~h}$ or immobilized MAb G19-4 (ANTI-CD3) plus MAb 9.3 (ANTI-CD28) 1 $\mu \mathrm{g} / \mathrm{ml}$ for $6 \mathrm{~h}$. The cells were harvested and the RNA was extracted and equalized for rRNA (top) on nondenaturing gels. Northern blots were sequentially hybridized with IL-3-, IL-2-, and HLA-specific cDNA probes. The IL-3 probed blot was exposed to film for $12 \mathrm{~d}$. RNA expression was compared by scanning densitometry.

\section{Results}

Induction of IL-3 gene expression by anti-CD3 or anti-CD3 with anti-CD28. To determine if stimulation of the TCR/CD3 pathway of $T$ cell activation induced IL-3 gene expression, $T$ cells were activated with anti-CD3 for 1-36 h. Stimulation of T cells by anti-CD 3 MAb alone induced IL-3 gene transcription with maximal mRNA accumulation at $6 \mathrm{~h}$. In view of the previously described ability of anti-CD28 to augment antiCD3-induced expression of lymphokines (10), T cells were also stimulated with anti-CD3 and anti-CD28 MAbs. This resulted in an approximately three- to fivefold augmentation of IL-3 expression (as evaluated by scanning densitometry) compared with stimulation by anti-CD3 alone. The time course of induction was not altered by anti-CD28, with maximal IL-3 message accumulation at $6 \mathrm{~h}$ (Fig. 1).

Induction of IL-3 gene expression by PHA. Previous attempts to induce IL-3 gene expression with lectin alone have been largely unsuccessful $(8,9)$. Since PHA is unable to stimulate purified $T$ cells in the absence of macrophages (26) we attempted to induce IL-3 gene expression by PHA stimulation of unseparated PBMC. For comparison, purified peripheral blood $\mathrm{T}$ lymphocytes were stimulated with immobilized antiCD3 alone or immobilized anti-CD3 plus soluble anti-CD28. PHA stimulation of PBMC induced IL-2 mRNA accumulation as effectively as did anti-CD3 stimulation (Fig. 2). However, PHA stimulation produced a lower level of IL-3 message expression than did anti-CD3. This suggests that PHA does not optimally induce the critical biochemical changes required for high level IL-3 gene expression.

Induction of IL-3 gene expression by phorbol ester and calcium ionophore. $\mathrm{T}$ cell activation by anti-CD3 results in increased intracellular calcium and in activation of protein kinase $C$ (11-15). To dissect the mechanism by which antiCD3 induces IL-3 gene expression, T cell activation was mimicked by the phorbol ester PDBU and the calcium ionophore ionomycin. Resting, purified T lymphocytes were incubated with PDBU alone, ionomycin alone, or PDBU and ionomycin. Activation by either PDBU or ionomycin did not result in a detectable IL-3 transcript. However, simultaneous stimulation with PDBU and ionomycin induced significant expression of the IL-3 gene (Fig. 3), indicating that neither increased intracellular calcium nor protein kinase $\mathrm{C}$ activation alone was sufficient for IL-3 gene expression.

IL-3 expression is restricted to $C D 28^{+} T$ cells and requires intracellular calcium release. Previous studies have shown that several $\mathrm{T}$ cell lymphokines could be induced not only by PMA and ionomycin, but by PMA plus stimulation of cell surface CD28 (10). This alternative pathway of T cell activation was used to help define the obligatory biochemical events required for IL-3 induction. PBMC, purified CD28 ${ }^{+} \mathrm{T}$ cells, or CD28T cells were stimulated with PMA and ionomycin or PMA and MAb 9.3 (anti-CD28; Fig. 4). The results define two requirements for IL-3 gene expression. First, the combination of PMA and ionomycin induces IL-3 message expression only in the $\mathrm{CD} 28^{+} \mathrm{T}$ cells, not in CD28- $\mathrm{T}$ cells. Thus, not only is IL-3 secretion restricted to $T$ cells but, in fact, it is restricted to the $\mathrm{CD} 28^{+}$subset of $\mathrm{T}$ cells. Second, incubation with PMA and anti-CD28, without ionomycin, failed to trigger IL-3 mRNA accumulation. In contrast, GM-CSF was readily inducible by PMA plus anti-CD28, and did not require ionomycin. Thus, this alternative $T$ cell activation pathway, known to readily induce $T$ cell secretion of GM-CSF, as well as other lymphokines, is not a legitimate pathway for IL-3 induction. T cell IL-3 gene induction, then, unlike GM-CSF gene induction, appears to occur via an obligately calcium-dependent pathway.

Half-life of IL-3 $m R N A$ in activated $T$ cells. We next asked whether the augmentative effect of anti-CD28 on anti-CD3induced IL-3 mRNA accumulation could be related to alterations in IL-3 message stability. Purified CD28 ${ }^{+} \mathrm{T}$ cells were coincubated for $3 \mathrm{~h}$ with anti-CD3 or anti-CD3 and anti-CD28 to induce IL-3 mRNA expression. At $3 \mathrm{~h}$ actinomycin D, an RNA synthesis inhibitor, was added to the incubation for 15-90 min. Total cellular RNA was isolated and IL-3 mRNA was measured by Northern blot analysis. The half-life of IL-3 mRNA after CD3 stimulation was $30 \mathrm{~min}$. In contrast, stimulation with anti-CD3 plus anti-CD28 prolonged the half-life of the IL-3 mRNA transcript to $>90$ min since no significant decline in IL-3 message was detected by densitometry (Fig. 5). The mechanism for the amplification of T cell IL-3 gene induction in cells activated by the CD28 pathway can, at least in part, be explained by the ability of anti-CD28 to stabilize the IL-3 message and thereby prolong IL-3 message half-life. 

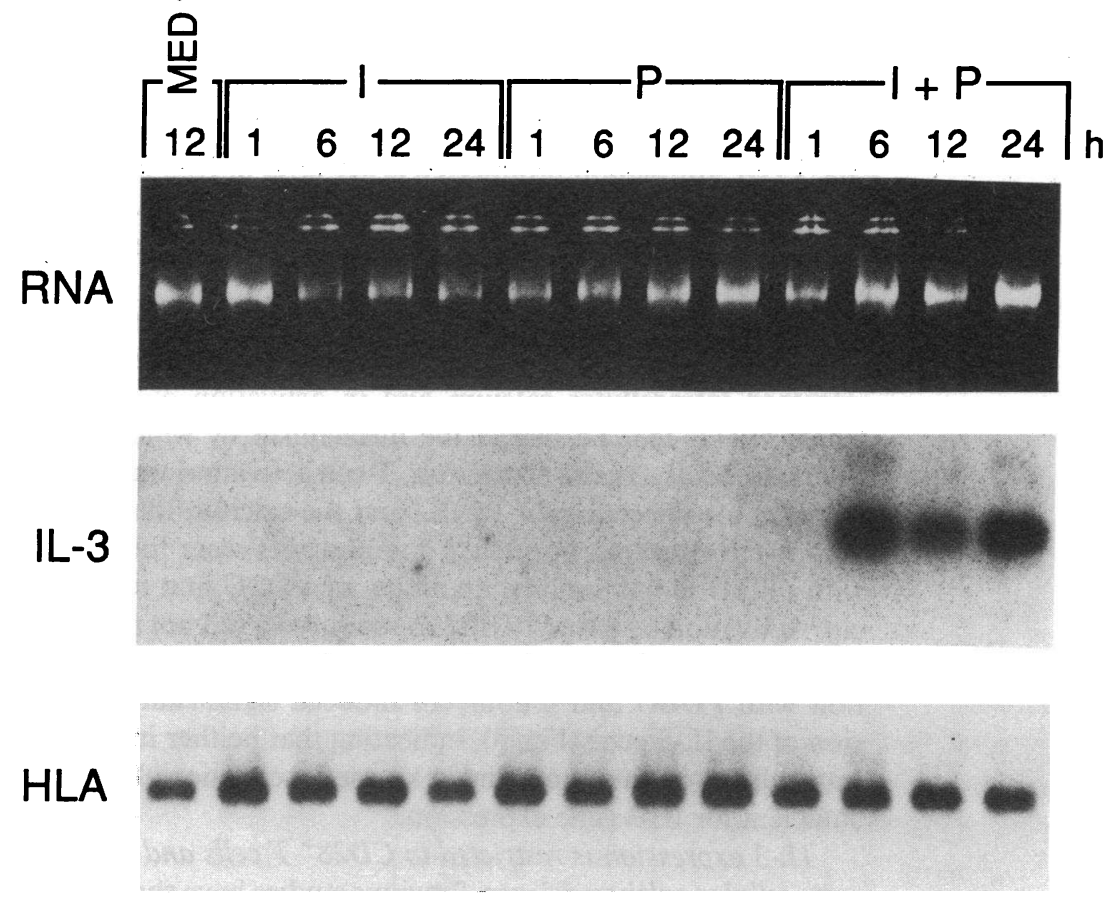

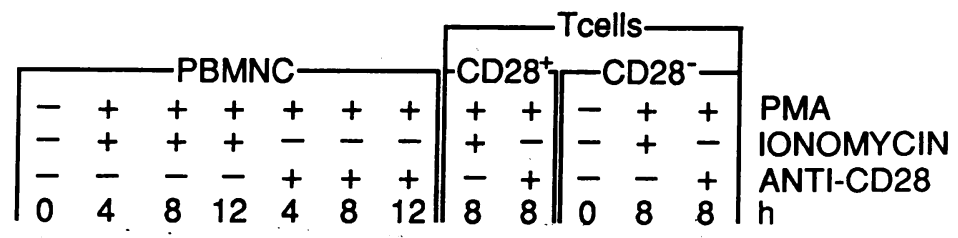

RNA

\section{GM-CSF}

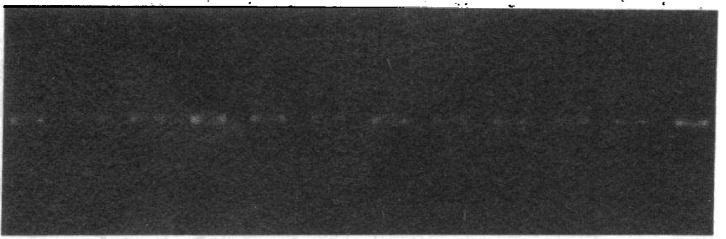

IL-3
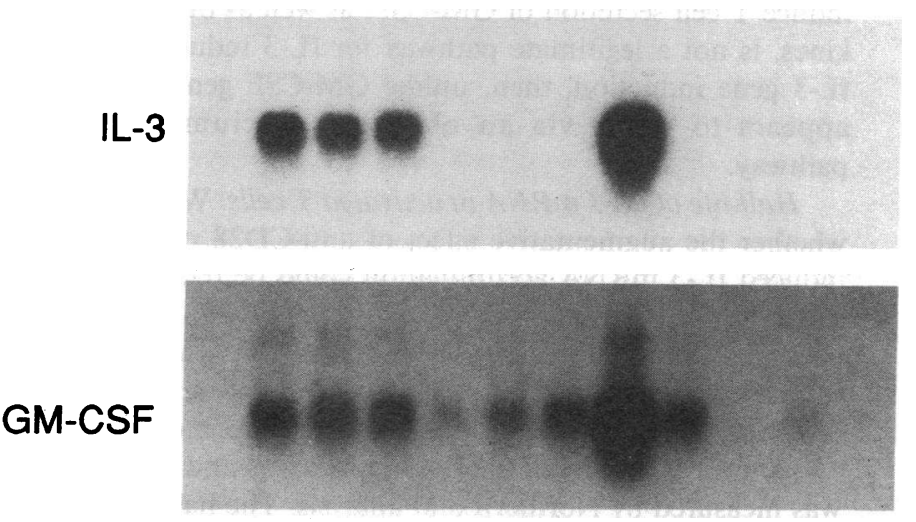

HLA

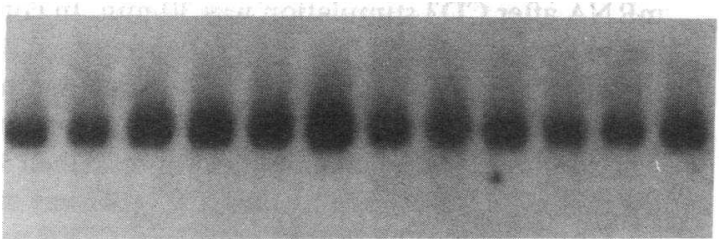

Figure 3. Induction of IL-3 gene expression by phorbol ester and calcium ionophore. Purified resting human peripheral blood $\mathrm{T}$ cells were cultured at $1 \times 10^{6} / \mathrm{ml}$ in medium $(M E D)$ for $12 \mathrm{~h}$, ionomycin $(I) 800 \mathrm{ng} / \mathrm{ml}$ for $1,6,12$, and $24 \mathrm{~h}$, phorbol ester, PDBU $(P) 100 \mathrm{ng} / \mathrm{ml}$ for $1,6,12$, and $24 \mathrm{~h}$, or ionomycin $800 \mathrm{ng} / \mathrm{ml}$ and PDBU $100 \mathrm{ng} / \mathrm{ml}$ for $1,6,12$, and $24 \mathrm{~h}$. The cells were harvested and the RNA was extracted and samples were equalized for rRNA on nondenaturing gels (top). Northern blots were transferred to nitrocellulose which was sequentially hybridized with IL-3- and HLA class I-specific CDNA probes. The film was exposed to the IL-3 probed filter for $16 \mathrm{~d}$ at $-70^{\circ} \mathrm{C}$.

Figure 4. IL-3 gene expression is restricted to the CD28+ $\mathrm{T}$ cell subset of PBMC. Resting human PBMC (PBMNC), resting human peripheral blood $\mathrm{CD} 28^{+} \mathrm{T}$ cells, or $\mathrm{CD} 28^{-}$cells were cultured with medium (PMA-, ionomy$\mathrm{cin}^{-}$, MAb 9.3-) for $0 \mathrm{~h}$, PMA $3 \mathrm{ng} / \mathrm{ml}$ and ionomycin $400 \mathrm{ng} / \mathrm{ml}$ for 4,8 , or $12 \mathrm{~h}$, or PMA $3 \mathrm{ng} / \mathrm{ml}$ and MAb 9.3 (anti-CD28) 1 $\mu \mathrm{g} / \mathrm{ml}$ for 4,8 , or $12 \mathrm{~h}$. The cells were harvested and the RNA was extracted and equalized for rRNA on nondenaturing gels (top). Northern blots were transferred to nitrocellulose and hybridized with IL-3-, GM-CSF-, and HLA-specific cDNA probes. The film was exposed for $3 \mathrm{~d}$. 

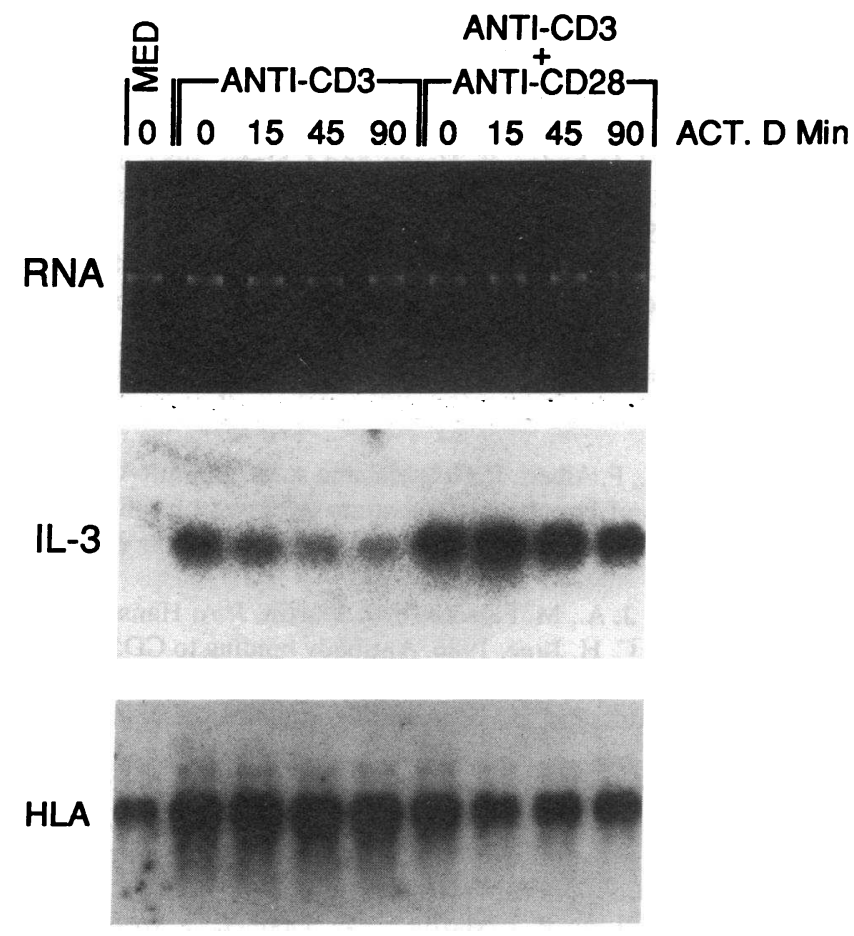

Figure 5. Half-life of IL-3 mRNA in activated T cells. Purified resting human peripheral blood CD28 ${ }^{+} \mathrm{T}$ cells were cultured for $3 \mathrm{~h}$ at 1 $\times 10^{6} / \mathrm{ml}$ in medium (MED), immobilized MAb G19-4 (ANTI-

$C D 3$ ), or immobilized MAb G19-4 (ANTI-CD3) and soluble MAb $9.3(A N T I-C D 28)$. Actinomycin D $10 \mu \mathrm{g} / \mathrm{ml}$ was added at $3 \mathrm{~h}$ and coincubated for $0,15,45$, and $90 \mathrm{~min}$. The cells were harvested and the RNA was extracted and equalized for rRNA on nondenaturing gels. Northern blots were transferred to nitrocellulose and hybridized with IL-3- and HLA-specific cDNA probes. The film was exposed to the IL-3 probed blot for $5 \mathrm{~d}$. RNA concentrations were compared by densitometry to determine half-life.

\section{Discussion}

Our data show that IL-3 gene expression is inducible via activation of the $T$ cell receptor/CD3 pathway and can be augmented by coactivation of the CD3 and CD28 pathways. Activation of the CD3 pathway may be mimicked by costimulation of $T$ cells with both PMA and ionomycin, also resulting in IL-3 gene expression. The ionomycin requirement appears to be obligate; ionomycin cannot be replaced by MAb 9.3 (antiCD28), as is the case with other lymphokines, including GMCSF. Thus, a calcium-dependent $T$ cell activation pathway is required for IL-3 gene induction.

IL-3 gene expression is inducible in purified T cell populations by stimulation of the TCR/CD3 complex with MAb G19-4 (anti-CD3; Fig. 1). In contradistinction to anti-CD3, the lectin PHA is a poor inducer of IL-3 gene expression. However, PHA and anti-CD3 induce similar levels of IL-2 gene expression (Fig. 2). These data suggest that the regulation of IL-3 and IL-2 expression is distinct and that while both anti-CD3 and PHA induce the intracellular biochemical signals required for IL-2 gene expression, only anti-CD3 efficiently elicits the appropriate intracellular signals required for significant IL-3 gene expression. Furthermore, since anti-CD3 induces IL-3 gene expression in purified T cell populations, neither accessory cell contact nor costimulation with other lymphokines such as IL-1 are required for anti-CD3-induced IL-3 gene expression.

IL-3 gene expression is also inducible when TCR/CD3 complex stimulation is mimicked by the combination of PMA and ionomycin (Fig. 3). In contrast, MAb 9.3 and PMA failed to induce IL-3 gene expression. This result was unexpected since the combination of MAb 9.3 and PMA does induce the gene expression of a number of other lymphokines, including GM-CSF (Fig. 4), tumor necrosis factor- $\alpha$, leukotriene, IL-2, and $\gamma \mathrm{INF}(10)$. Thus, since substitution of CD28 stimulation for ionomycin did not elicit IL-3 gene expression, we believe the IL-3 gene induction pathway is obligately calcium dependent. Furthermore, these data suggest that the mechanism by which stimulation of the CD28 pathway induces GM-CSF gene expression is not simply by increasing intracellular calcium. This conclusion is consistent with recent observations that show that soluble MAb 9.3 does not increase intracellular calcium (17). Alternatively, GM-CSF gene induction could simply require lower levels of intracellular calcium than IL-3 gene induction. Thus, the distinction between IL-3 and GMCSF gene expression appears to involve calcium regulation that is not bypassed by using CD28 stimulation.

From the point of view of lymphokine regulation, this calcium requirement is the first qualitative difference demonstrated between IL-3 and GM-CSF regulation. Kelso and Owens (27) have suggested that IL-3 has more restricted regulation than GM-CSF, even within a single T cell clone. Specifically, they hypothesized that one possible explanation for the differential regulation of GM-CSF and IL-3 was a difference in activation threshold between the two lymphokines, with IL-3 requiring the stronger stimulus. Niemeyer et al. have found similarities between IL-3 and GM-CSF in terms of kinetics (8). The present study both confirms the kinetic similarities observed by Niemeyer et al., while defining a distinct biochemical signal; i.e., a calcium requirement, which could account for the data of Kelso and Owens suggesting the more restricted IL-3 expression.

As with GM-CSF and other lymphokines, IL-3 gene expression is augmented by anti-CD28. Inhibition of de novo mRNA synthesis with actinomycin $\mathrm{D}$ demonstrates that addition of anti-CD28 to anti-CD3-stimulated CD28 ${ }^{+} \mathrm{T}$ cells results in prolongation of IL-3 transcript half-life (Fig. 5) showing that IL-3 message augmentation can be accounted for by mRNA transcript stabilization. Similarly, mRNA transcript stabilization appears to be the mechanism by which the CD28 pathway augments gene expression of other lymphokines, including GM-CSF (10).

The natural ligand for CD28 is unknown. However, given the transient nature of CD3-induced gene expression of many lymphokines, including IL-3, and the ability of CD28 to augment lymphokine message, the CD28 pathway may be a physiologic pathway for $\mathrm{T}$ cell lymphokine production. Activation of the CD28 pathway could have therapeutic implications since the ability to augment the expression of $\mathrm{T}$ cell lymphokines could be a useful tool in the management of a variety of cytopenic states.

In summary, IL-3 gene expression is inducible by the CD3/TCR pathway mimicked by PMA and ionomycin. IL-3 gene expression is calcium dependent. Hence, T cell IL-3 gene expression appears to be under stringent molecular regulation. 
Like GM-CSF and other lymphokines, IL-3 transcript accumulation is augmented by $\mathrm{CD} 28$, an effect that can be accounted for, at least in part, by stabilization of IL-3 mRNA. Lymphokine augmentation by CD28 may prove to be an important clinical strategy that allows manipulation of lymphokine levels.

\section{Acknowledgments}

We thank Trudy Ingland for her assistance in the preparation of this manuscript.

This work was supported in part by grants from the National Institutes of Health (NIH) and the Naval Medical Research and Development Command. Dr. Turka and Dr. Emerson are recipients of NIH Clinical Investigator Awards.

\section{References}

1. Nathan, D. G., and C. A. Sieff. 1987. The biological activities and uses of recombinant granulocyte-macrophage and multi-colony stimulating factors. Prog. Hematol. 15:1-18.

2. Clark, S. C., and R. Kamen. 1987. The human hematopoietic colony-stimulating factors. Science (Wash. DC). 236:1229-1237.

3. Emerson, S. G., Y.-C. Yang, S. C. Clark, and M. W. Long. 1988. Human recombinant granulocyte-macrophage colony stimulating factor and interleukin 3 have overlapping but distinct hematopoietic activities. J. Clin. Invest. 82:1282-1287.

4. Bot, F. J., L. Dorssers, G. Wagemaker, and B. Lowenberg. 1988 Stimulating spectrum of human recombinant multi-CSF (IL-3) on human marrow precursors. Importance of accessory cells. Blood. 71:1609-1614.

5. Sonoda, Y., Y.-C. Yang, G. G. Wong, S. C. Clark, and M. Ogawa. 1988. Analysis in serum-free culture of the targets of recombinant human hematopoietic growth factors: interleukin 3 and granulocyte/macrophage-colony-stimulating factor are specific for early developmental stages. Proc. Natl. Acad. Sci. USA. 85:4360-4364.

6. Sieff, C. A., S. Tsai, and D. V. Faller. 1987. Interleukin 1 induces cultured human endothelial cell production of granulocyte-macrophage colony-stimulating factor. J. Clin. Invest. 79:48-51.

7. Broudy, V. C., K. Kaushansky, G. M. Segal, J. M. Harlan, and J. W. Adamson. 1986. Tumor necrosis factor type alpha stimulates human endothelial cells to produce granulocyte/macrophage colonystimulating factor. Proc. Natl. Acad. Sci. USA. 83:7467-7471.

8. Niemeyer, C. M., C. A. Sieff, B. Mathey-Prevot, J. Z. Wimperis, B. E. Bierer, S. C. Clark, and D. G. Nathan. 1989. Expression of human interleukin-3 (multi-CSF) is restricted to human lymphocytes and $\mathrm{T}$ cell tumor lines. Blood. 73:945-951.

9. Yang Y.-C., A. G. Ciarletti, P. A. Temple, M. P. Chung, S. Kovacic, J. S. Witek-Giannotti, A. C. Leary, R. Kriz, R. E. Donahue, G. G. Wong, and S. C. Clark. 1986. Human IL-3 (multi-CSF): identification by expression cloning of a novel hematopoietic growth factor related to murine IL-3. Cell. 47:3-10.

10. Thompson, C. B., T. Lindsten, J. A. Ledbetter, S. L. Kunkel, H. A. Young, S. G. Emerson, J. M. Leiden, and C. H. June. 1989. CD28 activation pathway regulates the production of multiple T-cellderived lymphokines/cytokines. Proc. Natl. Acad. Sci. USA. 86:13331337.

11. Chatila, T., R. Wong, M. Young, R. Miller, C. Terhorst, and R.
Geha. 1989. An immunodeficiency characterized by defective signal transduction in T lymphocytes. N. Engl. J. Med. 320:696-702.

12. Oettgen, H. C., and C. Terhorst. 1987. The T-cell receptor-T3 complex and T-lymphocyte activation. Hum. Immunol. 18:187-204.

13. Weiss, A., J. Imboden, K. Hardy, and J. Stobo. 1987. The role of the antigen receptor/T3 complex in T-cell activation. Adv. Exp. Med. Biol. 213:45-49.

14. Weiss, A., J. Imboden, R. Wiskocil, and J. Stobo. 1984. The role of T3 in the activation of human T cells. J. Clin. Immunol. 4:165-173.

15. Nishizuka, Y. 1984. The role of protein kinase $C$ in cell surface signal transduction and tumor promotion. Nature (Lond.). 308:693698.

16. Truneh, A., F. Albert, P. Golstein, and A. M. Schmitt-Verhulst. 1985. Early steps of lymphocyte activation bypassed by synergy between calcium ionophores and phorbol ester. Nature (Lond.). 313:318-320.

17. Ledbetter, J. A., M. Parsons, P. J. Martin, J. A. Hansen, P. S. Rabinovitch, and C. H. June. 1986. Antibody binding to CD5 (Tp67) and Tp44 T cell surface molecules: effects on cyclic nucleotides, cytoplasmic free calcium, and cAMP-medicated suppression. J. Immunol. 137:3299-3305.

18. June, C. H., J. A. Ledbetter, M. M. Gillespie, T. Lindsten, and C. B. Thompson. 1987. T-cell proliferation involving the CD28 pathway is associated with cyclosporin-resistant-interleukin 2 gene expression. Mol. Cell. Biol. 7:4472-4481.

19. Ledbetter, J. A., P. J. Martin, C. E. Spooner, D. Wofsy, T. T. Tsu, P. G. Beatty, and P. Gladstone. 1985. Antibodies to Tp67 and Tp44 augment and sustain proliferative responses of activated $T$ cells. J. Immunol. 135:2331-2336.

20. Chirgwin, J. M., A. E. Przybyla, R. J. MacDonald, and W. J. Rutter. 1979. Isolation of biologically active ribonucleic acid from sources enriched in ribonuclease. Biochemistry. 18:5294-5299.

21. Thompson, C. B., P. B. Challoner, P. E. Neiman, and M. Groudine. 1986. Expression of the c-myb proto-oncogene during cellular proliferation. Nature (Lond.). 319:374-380.

22. Lindsten, T., C. H. June, C. B. Thompson, and J. M. Leiden. 1988. Regulation of $4 \mathrm{~F} 2$ heavy-chain gene expression during normal human T-cell activation can be mediated by multiple distinct molecular mechanisms. Mol. Cell. Biol. 8:3820-3826.

23. Mosmann, T. R., and R. L. Coffman. 1987. Two types of mouse helper T-cell clone: implications for immune regulation. Immunol. Today. 8:223-227.

24. Wong, G. G., J. S. Witek, P. A. Temple, K. M. Wilkens, A. C. Leary, D. P. Luxenberg, S. S. Jones, E. L. Brown, R. M. Kay, E. C. Orr, C. Shoemaker, D. W. Golde, R. J. Kaufman, R. M. Hewick, E. A. Wang, and S. C. Clark. 1985. Human GM-CSF: molecular cloning of the complementary DNA and purification of the natural and recombinant proteins. Science (Wash. DC). 228:810-815.

25. Sood, A. K., D. Pereira, and S. M. Weissman. 1981. Isolation and partial nucleotide sequence of a cDNA clone for human histocompatibility antigen HLA-B by use of an oligodeoxynucleotide primer. Proc. Natl. Acad. Sci. USA. 78:616-620.

26. Davis, L., R. Vida, and P. E. Lipsky. 1986. Regulation of human $\mathrm{T}$ lymphocyte mitogenesis by antibodies to CD3. J. Immunol. 137:3758-3767.

27. Kelso, A., and T. Owens. 1988. Production of two hemopoietic growth factors is differentially regulated in single $\mathrm{T}$ lymphocytes activated with an anti-T cell receptor antibody. J. Immunol. 140:11591167. 